\title{
Self-Employed Workers: A Comparison Group For Organizational Psychology ${ }^{1}$
}

\author{
Dov EDEN ${ }^{2}$ \\ The University of Michigan
}

\begin{abstract}
By neglecting self-employed workers, organizational psychology has deprived itself of a potentially useful comparison group for the purposes of ascertaining the effects of work organizations on their members and of investigating the effects of particular organizational variables. Reasons for this neglect are discussed and examples of studies that would have been strengthened by the inclusion of a sample of self-employed workers as a comparison group are cited. The review of research on the self-employed includes studies in the areas of bureaucratization and professionalization, demography and economic behavior, mobility, social class, political behavior, and job satisfaction and mental health. No study of the job satisfaction of self-employed workers was found. Special attention is given to research employing the comparison of self-employed and wage-and-salary workers. It is concluded that due to lack of controls, little can be learned from available research findings about the effects of organizational membership on individual workers. Nonetheless, controlled use of this member-nonmember comparison appears promising as a means of assessing the effects of organizations on their members.
\end{abstract}

The self-employed are the invisible men of the psychology of work. Whether the field is called industrial, organizational, occupational, or business psychology, it is typically limited to that majority of the work force whose labor is employed by others. For most writers the self-employed simply do not exist. For example, Murrell (1970) has delineated an emerging field of study and practice by saying that "industrial gerontology will be concerned with older workers at all levels in an industrial organization, both those employed on $[s i c]$ administration and those on the shop floor" (p. 72). Self-employed workers were excluded

${ }^{1}$ This article is based on Chapters I and II of the author's doctoral dissertation, completed at The University of Michigan while his name was B. D. Fine. The author is deeply indebted to Stanley E. Seashore, who chaired the doctoral committee, and to Earnest Harburg, Robert L. Kahn, Daniel Katz and J. B. Ritchie who served on the committee. Work on the dissertation was supported by Grant No. 91-24-70-49 from the Manpower Administration, United States Department of Labor.

${ }^{2}$ Now at the Department of Labor Studies, Tel-Aviv University, Ramat Aviv, Tel-Aviv, Israel.

186

Copyright (C) 1973 by Academic Press, Inc.

All rights of reproduction in any form reserved. 
from industrial gerontology despite the fact that older workers are disproportionately self-employed. Also writing about problems of the aged, S. Fine (1970) sought to shift the emphasis from one's job to one's career: "Careers are not jobs. They involve jobs-but they are a great deal more. In careers the focus is on the worker and his relationship to an organization. In jobs the focus is simply on getting a job of work done" (p. 43, italies added). The implication is that the concept of career does not apply to workers who are self-employed. While Weber (1947) stated that the bureaucracy provides a career for the official, with "a system of 'promotion' according to seniority or to achievement or both" (p. 334), it does not follow that no career is possible in nonbureaucratic settings.

Discussing occupational choice, Vroom (1964) has pointed out that people not only choose occupations but also choose organizations.

Typically a person selects his occupation before deciding on an organization. He decides to become a doctor before ehoosing a hospital with which to affiliate or decides to become an engineer before joining a particular corporation. . . Occupational and organizational choices are not independent of one another. Choice of occupation of lawyer, for example, limits the organizational choice to those institutions employing lawyers (p. 50).

Vroom did not consider the option of choosing no organization, as solo lawyers do, and as about $10 \%$ of the nonfarm work force do.

\section{Reasons for Exclusion of Self-employed}

There are many reasons why the self-employed have been so consistently excluded from studies of work. Perhaps the foremost is the fact that these workers have been perceived as a continually shrinking segment of the work force, whose importance has diminished with their numbers in face of the growing number and size of organizations. There has, indeed, been a secular decline in the proportion of the work force that is self-employed, but this is in large part accounted for by the passing of the independent farmer. Furthermore, as Mayer (1947) has cautioned,

the persistence and durability of small business as a group, as an institution, must not be confused with the economic stability of the individual small enterprise. Much . . . confusion . . results from the fact that these two phenomena are not clearly distinguished. While the total number of small enterprises and the total volume of their business activity shows relatively little change, the composition of the group changes rapidly (p. 336).

In recent years the percentage of self-employed workers in the nonagricultural work force has been consistently close to $10 \%$. Phillips (1962) has shown that, contrary to the trend among the self-employed 
as a whole, "the percentage of the nonagricultural self-employed in the labor force has declined little, if any, and their numbers have risen sharply from the depression and wartime lows" (p. 20). Phillips cited Department of Commerce estimates showing that active proprietors of unincorporated nonagricultural enterprises comprised almost $10 \%$ of the civilian labor force both in 1929 and in 1960, despite fluctuations associated with the depression and the war in the intervening years.

In attempting to reconcile different estimates of the number of nonfarm self-employed workers, Leveson (1968b) pointed out that many proprietors of small businesses who have elected in recent years to shift to corporate status for purposes of taxation and limited liability are similar in other respects to unincorporated proprietors. Nonetheless, most estimates of the number of self-employed workers omit the small corporate proprietors. Leveson concluded, "Reductions in self-employment as a percent of all employment have been greatly overstated in recent years as a result of the growing importance of the corporate form of organization" (p. 48). Thus, the image of the fading entrepreneur is inaccurate since in recent years the decline has evidently leveled off, and may have reached an asymptotic level. Mayer's conclusion that "in terms of economic survival small business as a group appears to be remarkably persistent and durable" (p. 335) is still credible today.

A second reason for neglect of the self-employed is that they are not as accessible as organization members. Members of work organizations can be made available to an investigator en masse, yielding more data for the dollar than a similar number of self-employed workers scattered over a much wider geographical area and not deliverable to the researcher in large, convenient batches. Wicker (1969) has pointed out that studies that attempt to validate attitude measures by comparing the responses of persons assumed to be at opposite ends of an attitude continuum have limited generality since "known groups" are used. Persons of middling attitude and those who are not members of organized groups are omitted since they are unavailable to investigators. Thus, exclusion of nonmembers is not a research practice unique to organizational psychologists.

A third reason is substantive. Vroom (1964) explained that one reason for the relative dearth of research on job content as a determinant of job satisfaction is a tendency for psychologists to favor studying the effects of social relationships such as those between a superior and his subordinates or among peers. The same substantive preferences would lead psychologists to favor studying the interpersonally richer milieux of organizations and to neglect the self-employed. Indeed, many problems of interest to psychologists can be studied only in organizations. 
These include such issues as, for example, the effectiveness of different means of integrating organizational units, and the relationship of work group size to performance and attitudes.

Finally, since much organizational research is initiated by the clientsubject, and since research tends to be oriented towards the sources of its financial support, the self-employed, with few resources to spare for research and development, draw little or no attention from supportdependent researchers.

\section{ARGUMENT FOR INCLUDING SELF-EMPLOYED WORKERS IN ORGANIZATIONAL RESEARCH}

\section{The Effects of Membership}

Much of the literature on organizations supports the contention that membership in organizations brings unwanted results to individuals. Psychologists are especially inclined to focus their attention on the individual, but other investigators of organizational phenomena have also implied that organizational membership has negative consequences for individuals. Weber (1947) considered bureaucracy both indispensable for society's continued functioning and inescapable for the individual:

When those subject to bureaucratic control seek to escape the influence of
the existing bureaucratic apparatus this is normally possible only by creat-
ing an organization of their own which is equally subject to the process of
bureaucratization. . . Without it (the existing bureaucratic apparatus),
a society like our own - with a separation of officials, employees, and
workers from ownership of the means of administration, dependent on dis-
cipline and on technical training - could no longer function (p. 338).

Weber did not specify why individuals might seek to escape from bureaucratic structures. Working at the sociological level of analysis, he largely neglected to examine the effects of bureaucracy on individual participants. He did imply, however, that work in nonorganizational settings was free of the kind of control over individual behavior experienced by members of bureaucratic organizations:

The capitalist entrepreneur is, in our society, the only type who has been able to maintain at least relative immunity from subjection to the control of rational bureaucratic knowledge. All the rest of the population have tended to be organized in large-scale corporate groups which are inevitably subject to bureaucratic control (p. 339).

Merton (1957) has explained why workers gravitate to organizations:

Bureaucratization. makes readily visible what was previously dim and obscure. More and more people discover that to work, they must be employed. For to work, one must have tools and equipment. And tools and equipment 
are increasingly available only in bureaucracies, private or public. Consequently, one must be employed by the bureaucracies in order to have access to tools in order to work in order to live (pp. 68-69).

The choice of words in these quotations strongly implies the operation of powerful forces that coerce the unwilling into employee status and subjugation to a kind of control from which workers had been free in the past. This change of work milieu from some prebureaucratic setting to employment in large-scale organizations is viewed as a fall. The popular images of the "organization man," the generally negative connotation of the term bureaucracy, and the abundance of normative prescriptions for organizational changes designed to restore to the individual member his autonomy and sense of self-worth, are all phenomena that share the theme that organizations have wrought undesirable consequences for the individual.

Some psychologists have described in more explicit terms how organizations affect individual members. Perhaps the foremost is Argyris $(1957,1964)$ who has written most eloquently about the incompatibility of individuals and organizations, and its consequences. His first proposition states: "There is a lack of congruency between the needs of individuals aspiring for psychological success and the demands of the (initial) formal organization" (1964, p. 40, parentheses in original). He summarized his views as follows:

The formal organization ... and the administrative control system typically used in complex formal organizations may be viewed as part of a grand strategy to organize human effort to achieve specific objectives. . . The strategy creates a complex of organizational demands that tend to require individuals to experience dependence and submissiveness and to utilize few of their relatively peripheral abilities. The degree of dependency, submissiveness, and so on, tends to increase as one goes down the chain of command and as the job requirements and managerial controls direct the individual; they decrease as one goes up the chain of command and as the individual is able to control the job requirements (p. 58).

In his introduction to The Organization Man, Whyte (1956) stressed that the people described in his book "are not workers, nor are they the white-collar people in the usual, clerk sense of the word. These people only work for The Organization. The ones I'm talking about belong to it as well. . . Only a few are top managers or ever will be" (p. 3, italics in original). Whyte's description is focused on middle managers and the impact of the organizations they "belong to" upon them - their education, their careers, their nonwork life. Emphasizing that membership in organizations is a major factor contributing to the decline of individualism, he expressed his contempt for organizations in the following sentence: "Of all the forms of wanton self-destruction ... there is none 
more pathetic than that in which the human individual demands that in the vital relationships of life he be treated not as an individual but as a member of some organization" (p. 66).

Presthus (1962) has likewise described the organization as having undesirable effects on individuals in general:

Today, however, big organizations tend to view man instrumentally. Their aequisitive demands restrict his discretion; they subordinate his values and aspirations to the major purposes of the organization. . . . Man, in effect, is made for the organization. He may succeed and prosper within it, but the organization always defines the terms of success. Yet, given his dignity as a human being and his capacity for reason, man ought not to be viewed as an instrument (pp. 25-26, italics in original).

Their (big organizations') impersonal, long-range objectives, patent control mechanisms, size, and tendency toward absolutism may have dysfunctional, anxiety-producing results for their members. Such byproducts, the unanticipated consequences of the bureaucratic situation, become most clear when organizational claims are set against democratic ideals of free expression, individual worth, and spontaneity (p. 17).

Revising the Marxian view that it is the propertylessness of the worker in the capitalist societies that most basically contributes to his alienation, Blauner (1964) stated:

Today, most social scientists would say that alienation is not a consequence of capitalism per se but of employment in large-scale organizations and impersonal bureaucracies that pervade all industrial societies $(p, 3)$.

Inherent in the techniques of modern manufacturing and the principles of bureaucratic industrial organization are general alienating tendencies (p. 166).

For Mills (1951) the special victim of bureaucratization is the whitecollar worker:

In the eighteenth and nineteenth centuries, rationality was identified with freedom. The ideas of Freud about the individual, and of Marx about society, were strengthened by the assumption of the coincidence of freedom and rationality. Now rationality seems to have taken on a new form, to have its seat not in individual men, but in social institutions which by their bureaucratic planning and mathematical foresight usurp both freedom and rationality from the little individual men caught in them. The calculating hierarchies of department store and industrial corporation, of rationalized office and governmental bureau, lay out the gray ways of work and stereotype the permitted initiatives. And in all this bureaucratic usurpation of freedom and rationality, the white-collar people are the interchangeable part of the big chains of authority that bind the society together (p. xvii).

The above are examples of rather explicit statements about the negative consequences of organizational membership. A far greater proportion of the literature on organizations implies that organizational mem- 
bership leads to negative outcomes for individuals, but does not discuss this explicitly. The value judgment is left to the reader. When organizations are described as posing constraints to behavior, fostering dependence, restricting autonomy, imposing hierarchical control on members, exchanging inducements for contributions, producing stresses that put strain on members, reducing spontaneity of behavior, and encouraging conformity, many might well conclude that organizations are having undesirable effects on their members who, for a variety of reasons, have no real choice but to maintain their membership. A further implication is that these outcomes are unique to organizational settings and would not exist in a world without organizations. Thus, explicitly and implicitly a large part of the literature is consistent with the conclusion that membership in organizations leads to undesired outcomes for individuals.

\section{The Missing "Control Group"}

The effects of work organizations per se on their members cannot be studied rigorously without reference to a comparison group of workers who are not employed in organizations. Without such a group of nonmembers it is difficult to determine unequivocally whether membership in work organizations has less desirable outcomes than does work in nonorganizational settings. The many studies which have investigated members only and have purported to show the effects of organizations on their members can be criticized for having neglected to provide a standard of comparison that could establish that nonorganizational work settings are at all different in their effects on workers. The only necessarily organizational feature of many studies in "organizational psychology" is that their subjects are all members of organizations. Often, the variables whose effects are studied need be regarded as "organizational" only by the limited perspective of the investigator, and could be studied just as well using working nonmembers as subjects. Such a population of nonmember breadwinners exists and can provide workers to serve as "control" groups in organizational studies. They are the $10 \%$ of the work force who are self-employed.

\section{Appropriation of Features of Work-in-General}

\section{As Organizational Characteristics}

The disuse of self-employed workers as a comparison group has made it difficult to test the contention that work organizations have ill-effects upon their members, apart from the effects of work per se. Neglect of the self-employed has also led to the widespread tendency to treat characteristics of work settings in general as organizational variables. An example of a characteristic usually attributed to organizations that can be 
found in the nonorganizational work settings of the self-employed is impersonality. Organization members are said to react negatively to the impersonality inherent in bureaucratic structure. However, impersonality is not limited to bureaucratic organizations. The relationship between the self-employed professional and his client is in some respects impersonal by design. Patients allow their physicians to practice certain diagnostic and treatment procedures upon them that would take on entirely different (and personal) meaning in a nonprofessional social context. The physician may remain personally detached from his patient and thereby preserve his professionalism. Impersonality is also a feature of the relationship between the shopkeeper and his customer. Conventions of courtesy and fixed prices make many interactions between shopkeeper and customer nearly automatic and largely depersonalized, each party to the relationship being merely instrumental to the other in the exchange of goods or services; all this with no bureaucratic organizational structure. Indeed, Bonjean and Grimes (1971) found that impersonality was more consistently and more significantly associated with measures of alienation among self-employed businessmen than among organizationally employed managers and workers. Thus, impersonality and its effects have been found among persons who work in nonorganizational settings.

Weber cited the control of behavior of office incumbents by rules and regulations as a defining characteristic of bureaucracy. If one considers the control of behavior of the self-employed, it is apparent that rules and regulations determine a great deal of their work behavior. Few means of livelihood are free of constraints established by public agencies and professional or trade associations. There are binding rules and regulations that limit autonomy by determining what hours a shop may be open, what treatments a physician may use, levels of prices or fees, where various livelihoods may be practiced, and other aspects of selfemployed work.

A final example of an "organizational" characteristic found in nonorganizational work settings is the tendency of the employment situation to enforce conformity in workers. Obviously, there are great pressures on the self-employed to conform to a rather narrow range of behaviors while at work. Dependence on a loyal clientele for future livelihood serves as a powerful incentive to meet client expectations even with respect to nonwork behaviors. One suspects that expectations of clients and customers can induce in the self-employed the public display of political views and even religious affiliations, as has been observed among organization members (Dalton, 1959).

The argument here is complementary to that of Katz (1968), who has observed: 
Independence exists within most social arrangements. Be they large-scale organizations, such as hospitals, schools, or prisons, or small-seale interactions among a few persons, social arrangements contain not only controlled and predictable activities, but also activities that are relatively autonomous p. 4).

Organizational structure includes relatively controlled and relatively autonomous spheres (p. 49, italics in original).

Thus, Katz noted a bias in the literature that has obscured the autonomy inherent in organizations.

An analogous bias has veiled the constraints on workers' behavior in nonorganizational settings. Self-employment, like organizational employment, includes relatively controlled and relatively autonomous spheres of activity. In the past self-employment has been idealized by both workers and scientific investigators because of the absence of a bureaucratic control structure. Whether or not there is greater autonomy and less control in self-employment in contrast to organizational work settings, and whether there are differences in individual well-being in the different settings, should be regarded as empirical questions rather than as matters to be resolved by definition. Perhaps much of what has been attributed to organizations should be attributed instead to work in general, to urbanization, to industrialization, to technology, to the human condition, or to all of these. All these other societal conditions affect the modern worker in greater or lesser degree irrespective of his work setting. That many ills are attributed to organizations instead of to work itself is perhaps a manifestation of the tremendous value placed upon work by Western tradition. Norms against the deprecation of work are strong; norms against the deprecation of organizations are very weak, if they exist at all. To the extent that properties attributed to organizations also characterize the nonorganizational work settings of the self-employed, theory and research have been focused too narrowly upon organizations and their effects, and not enough upon work (in all settings) and its effects. If, on the other hand, it could be shown that "nonmembers" are psychologically better off than employees of organizations, then the argument that organizations have ill effects on their members would be strengthened, and the need for organizational improvement would become all the more urgent.

Weber's (1947) definition of organization implies a comparison between organizations and lone self-employed workers:

A profit making organization (Erwerbsbetrieb) is spoken of wherever there is continuous permanent co-ordinated action on the part of an entrepreneur. Such action is in fact unthinkable without an "organization," though, in the limiting case, it may be merely the organization of his activity, without any help from others (p. 222, parentheses and italics in original). 
Students of organizations have not taken seriously the notion of the individual entrepreneur working alone as a limiting case for the study of organizational variables. A move in this direction was taken by Hall (1963), who demonstrated the applicability of the concept of bureaucracy to small organizations. He compared seven small organizations, ranging in size from 10 to 33 members, to 10 larger organizations ranging in size from 65 to 3096 employees, and found that the small organizations were not significantly different from the large organizations on four of the six dimensions of bureaucracy measured. Though the large organizations were significantly more bureaucratic with regard to hierarchy of authority and rules, no significant differences were found for division of labor, procedures, impersonality, and technical qualifications. Hall, thus, found that several dimensions of bureaucracy previously regarded as features of large-scale organizations are characteristic of small organizations too. A question raised in the present article is whether much of what has been regarded as characteristic of bureaucratic organizations, large and small, applies also to nonorganizational work settings.

In addition to the global question of the effects of organizational membership on individual outcomes, the inclusion of self-employed workers as a comparison group would strengthen studies of the effects of particular aspects of organizations on their members. An example of the many investigations that would have benefited from the inclusion of selfemployed workers as a comparison group is Argyris' (1960) study of the effects of formal organization structure on members. He compared two departments differing in technology and in the skill level of their employees. The two departments were equivalent in degree of both directive leadership and managerial control, and they shared the same "environmental culture of the organization." Argyris presented data that "confirm the hypothesis that the technology has an impact upon predispositions and activities of human beings." He used the different levels of technology to operationalize the construct "formal organization structure," and concluded that his data show the effects of such structure.

One can ask just what it is that makes this an organizational study. Of course, it was conducted in order to test the investigator's theory of organizations. The title labels it a study of "individual actualization in complex organizations." Furthermore, the subjects were all employees of an industrial organization. However, technology, the study's independent variable, is certainly not a manifestation of "formal organization structure" alone. Self-employed dentists and self-employed gardeners do not normally operate within a formal organizational structure, and yet they use quite different technologies. Whatever findings result from a study designed like Argyris' are applicable to workers in organiza- 
tional and nonorganizational work settings alike. Had Argyris included two groups of self-employed workers, each group using a different technology, he might have found differences between them as well as between the two groups of members. One can disagree with Argyris' statement that "in studying the problems of industrial mental health, it may be that man may not be separated from the organization. The unit becomes the individual-organization" (p. 235). Indeed, our knowledge would be increased if more were known about how the mental health of workers employed by organizations differs from the mental health of self-employed workers not subject to formal organization structure. While one can agree with Argyris that "Without organizations, the researcher on organizations would have nothing to say," the converse is not true; studying organizations alone will not bring us to full understanding of them. Individual actualization in complex organizations must be compared to individual actualization in nonorganizational settings in order to understand fully the impact of organizations on members.

Another example of the limited value of research that omits the selfemployed is in the study of the effects of organizational level on attitudes and behavior. Organizational level and occupational level are obviously correlated. Workers with the least skill tend to be concentrated at the lowest level of the organization, and occupational status or prestige increases as one ascends the organizational hierachy. Thus, these two variables are confounded in most research involving either one of them. For example, Porter and Lawler (1965) gave the following reason for eliminating studies of occupational level from their review of the litera-. ture on the effects of organization structure on behavior and attitudes:

In surveying the literature pertinent to organizational levels and their impact on, or relationship to job attitudes and behavior, we encounter several difficult boundary or definitional problems. The first such problem concerns the question of whether studies of occupational levels should be included in the review. For our purpose, since the focus is on organizational structural variables, such occupational level studies will be generally omitted on the basis that they ordinarily investigate levels in a societal or cultural setting rather than levels within an organizational setting (pp. 25-26; italics in original).

Implicit in their statement is the definition of an organizational study as one which includes only members of organizations. By eliminating the self-employed from consideration, the effects of the organizational variable are harder to isolate. To the extent that job attitudes are correlated with occupational level among self-employed workers, all studies of organization members that have obtained findings showing a relationship 
between organizational level and job attitudes are suspect, since differences in occupational level can account for the relationship.

An ironic example of the underutilization of the self-employed as a comparison group is the research of Kahn et al. (1964) on organizational stress. Although the self-employed were overrepresented in their national sample, comprising $17.4 \%$ of the respondents, they, along with the female respondents, were eliminated from the analysis in order to facilitate comparison of the national sample data to findings obtained from members of selected organizations as part of a more intensive companion study of many of the same variables. Thus, the investigators sampled the self-employed and then eliminated them from analysis. Analysis of the data from the self-employed respondents might have revealed that they are stricken by many of the same stresses reported by wage-andsalary workers, rendering the term "organizational stress" inappropriate and forcing a reconceptualization of some of the major variables. An appendix to their book provides percentage distributions on several dependent variables separately for self-employed and wage-and-salary workers. These data will be presented below.

To summarize the major argument in this section, the self-employed have been almost totally ignored by organizational (and other) psychologists. Investigations of the effects of organizational membership in general, and of various specific organizational variables, would be strengthened by studying self-employed workers as a "control group."

\section{RESEARCH ON SELF-EMPLOYED WORKERS}

The remainder of this article will discuss some of the diverse literature on the self-employed. Studies included were found by means of a systematic search, not of a defined set of journals, but of the sources with which the author is most familiar and other sources discovered by crossreferencing. A host of works were scanned for such key words as "selfemployment," "entrepreneur," "membership," "businessman," and "proprietor." The many studies conducted by economists and business administration specialists on the sources of failure of small business enterprises were not reviewed, since psychological variables are rarely measured in such investigations.

\section{Demographic Characteristics}

Leveson (1968a) examined the demographic characteristics of the nonagricultural self-employed, using 1960 census data. In comparison with the nonfarm labor force as a whole, women and blacks are underrepresented among the self-employed. For both men and women the percentage self-employed increases monotonically with age. For men the 
relationship between education and self-employment is curvilinear; a greater percentage of the least educated and of the most highly educated are self-employed. For women the relationship between education and self-employment appears to be erratic. The foreign born are more likely to be self-employed than are the native born, though this is in part explained by their higher ages. The self-employed are unequally distributed among industries and occupations. The percentage self-employed is lower in urban areas than in other areas, and is higher in the South than in other regions. Variations in industrial composition explain only part of these geographical differences. Leveson concluded that the evidence does not support the notion that self-employment is a haven for disadvantaged groups. This is primarily because the percentage self-employed rises with education even within age groups, and because the percentage of self-employed blacks is low. Leveson's findings clearly demonstrate that the self-employed are not a representative crosssection of the work force. Demographic differences will have to be controlled in studies comparing self-employed and wage-and-salary workers in terms of social-psychological variables.

\section{Economic Behavior}

A well-documented aspect of the economic behavior of the self-employed is that as a group they work more hours than do wage-andsalary employees. For example, in their survey of how Americans spend time in productive activities, Morgan, Sirageldin, and Baerwaldt (1966) found that the predictor that explained the greatest proportion of variance in the number of hours worked annually by heads of families was whether or not the head was self-employed. The $16 \%$ of the heads in the sample who were self-employed businessmen or farmers averaged nearly 600 more working hours per year, or about $12 \mathrm{hr}$ more per week, than wage-and-salary workers. Self-employment as such was less important than actual ownership of a business or farm, suggesting that "ownership and entrepreneurial opportunity, rather than the freedom to choose one's hours, is what makes the difference" (p. 21).

The only other difference found between self- and other-employed heads was that the self-employed and those not in the work force obtained lower scores than the remainder of the sample on an index of concern with progress. This index was constructed by combining four other indices measuring ambition and aspiration, planning and time horizon, achievement orientation, and receptivity to change. The authors suggested that this result might be an artifact produced by the scoring method used, or might indeed reflect a real tendency for selfemployed businessmen to be more resistant to change than wage-and- 
salary workers. The lower score for the self-employed in concern for progress is consistent with the findings of political sociologists, reviewed later, that this segment of society is more susceptible to the appeal of the politics of the radical right. Morgan et al. reported a negative finding that they termed "startling": Families who own a business or farm did not differ from the remainder of the sample on an index of caution and risk avoidance. Similarly, owners were similar to nonowners in receptivity to change and in social participation.

Whereas Morgan et al. included farmers in their self-employed category, Leveson reported data on hours worked by self-employed and wage-and-salary workers in nonagricultural industries. He found that the nonfarm self-employed exceed the wage-and-salary workers by an average of $8 \mathrm{hr}$ per week, as compared to $12 \mathrm{hr}$ reported by Morgan and. his coworkers, the difference being attributable to the exclusion of farmers. Phillips (1962) reported nonagricultural data almost identical to those reported by Leveson. Further analysis by Phillips and by Leveson showed that nearly one in five of both self- and other-employed workers works fewer than $35 \mathrm{hr}$ each week; the higher average hours worked by the self-employed results from the fact that $45 \%$ of them work more than $48 \mathrm{hr}$ per week, compared to only $15 \%$ of the wage-andsalary employees who work as many hours.

With regard to income, the census data analyzed by Phillips indicate that among year-round full-time male workers in 1958 and in 1959, median annual money earnings were higher for the self-employed than for either private wage-and-salary workers or government employees. However, women who were self-employed earned considerably less than women who earned wages or salary in either private industry or government. Similarly, Leveson (1968b) found that hourly earnings of the nonfarm self-employed in 1959 were generally higher than those of nonfarm wage-and-salary workers. In order to control demographic differences Leveson computed adjusted hourly earnings for the self-employed, removing the effects of race, age, sex, and education. The results indicated that the differences between self- and other-employed workers in these demographic characteristics accounted for about two-thirds of the original difference. However, the actual hourly earnings of the selfemployed still exceeded even their adjusted hourly earnings by an average of about $10 \%$. A breakdown by occupation showed that actual selfemployed hourly earnings surpassed the adjusted earnings in some occupations, notably professional, technical, and kindred workers, and clerical and kindred workers, but fell short of the adjusted earnings in other occupations, particularly among operatives and kindred workers and service workers. It appears from Leveson's analysis that while the 
self-employed on the average earn more than would be predicted from their demographic characteristics, those at higher occupational levels earn more by being self-employed, and those self-employed in lower-level occupations earn less by virtue of their self-employment. The gain at higher occupational levels more than offsets the loss at lower levels, resulting in an aggregate $10 \%$ bonus for the self-employed as a whole.

\title{
Mobility
}

Describing social mobility in Germany in the late nineteenth century, Weber wrote:

\begin{abstract}
At an earlier period every worker could be said to have been primarily interested in becoming an independent small bourgeois, but the possibility of realizing this goal is becoming progressively smaller. From one generation to another the most readily available path to advancement for both the skilled and semiskilled workers is into the class of technically trained individua's. . . Through the banks and corporate enterprises members of the lower middle class and the salaried groups have certain opportunities to rise into the privileged class (p. 427).
\end{abstract}

Recent empirical work has shown that organizations offer blue-collar workers dim prospects for upward intragenerational mobility and that self-employment holds relatively greater, though still limited, promise for working class advancement. Chinoy's (1955) study of automobile workers yielded dramatic evidence of the lack of opportunities in organizations for upward mobility among blue-collar workers. Forty-eight of the 62 workers he interviewed maintained their belief in the "American dream" by entertaining notions of escape from the factory to advancement through the ever-shrinking opportunities in private enterprise:

Most talk of leaving (the automobile factory) dealt with the traditional avenue of success, some kind of small business venture. Of the 48 who had thought of quitting, 31 suggested "a business of my own" as their goal. Six (other) workers wished to become independent farmers (p. 82; parentheses added).

Few of these men, however, took any concrete steps towards implementing their entrepreneurial goals. These goals were interpreted by Chinoy as "Utopian day dreams" that provide psychological escape from present factory life.

Lipset and Bendix (1963) reported labor mobility data for a sample of workers from Oakland, California which indicate that self-employment is in fact a more traveled avenue of mobility among manual workers than was suggested by Chinoy's much smaller sample of auto workers. They found that the greatest intragenerational mobility from manual to nonmanual jobs occurs among those who switch to self-employment. 
Forty-one percent of those who owned businesses at the time they were interviewed had been employed in manual occupations on their previous job. No other nonmanual occupational category had adsorbed nearly so high a percentage of manual workers. Furthermore, among those in nonmanual occupations, the self-employed were surpassed only by lower level white-collar workers in the percentage of their total career time they had spent in manual occupations and in the percentage of workers who had ever held manual jobs. The authors pointed out that such shifting may not always result in a change of status and income, and hence does not provide a ready estimate of how much genuine social mobility is involved.

Lipset and Bendix speak of "old" and "new" types of mobility. Manual workers move up via self-employment, while mobile persons in the white-collar occupations are mobile in a bureaucracy:

Since a good proportion of (proprietors) come from the manual occupations, it is probable that their only choice is between manual labor and proprietorship. . . . It is in part a by-product of the predominance of large scale organizations that those who head them have usually had a bureaucratic career. The "industrial bureaucrat," not the small independent businessman, is the one most likely to advance to the peak of the economic structure, both socially and economically. For these reasons the data on self-employed businessmen are of special interest. . .

Although only about 10 per cent of the American population (sic) are presently self-employed businessmen, it is obvious that a much larger part of the labor force has owned a business in the past, given the large turnover in this category . . over one-fifth of the members of the Oakland sample who are currently engaged in manual work were at some time in business for themselves ( $p p .176-77$ ).

Thus, for blue-collar workers self-employment appears to be not only a dream embodying traditional American ideals, but also an actual, though risky, means of attaining upward mobility denied them in large organizations.

The opinion that a shift from employee status to self-employment is a step upward in the social hierarchy is held not only by blue-collar workers. Many social scientists view self-employment as lending greater prestige to a given occupation. Presthus (1962) has pointed out that "students of mobility tend to undervalue farm proprietorship, while accepting movement from unskilled or skilled work into business proprietorship as a valid index of upward mobility" (p. 213, italics in original). Many of the standard occupational status codes used in research lump together all the self-employed, or all nonfarm proprietors, despite the tremendous variability within this category of workers. Furthermore, the self-employed are often ranked high in occupational status 
despite the fact that many workers so classified are barely eking out a living.

A typical example of this practice of rendering self-employment higher in social status by definitional fiat is Reiss' (1955) study of occupational mobility among five different levels of professional workers. A move to self-employment was categorized separately as "upward to self-employment" and shifts out of self-employment were classified separately as moves "downward from self-employment." No justification for this procedure was given by the investigator. Lipset and Bendix defined selfemployed businessmen as nonmanual workers despite the fact that a proprietor may work with his hands most of the time. Thus, presumably, a carpenter in the employ of a construction firm would be classified as a manual worker, whereas a self-employed carpenter would be considered nonmanual. Again, self-employment is arbitrarily defined as having higher status than organizational employment. It is impossible to determine what proportion of the "nonmanual" business owners in the Oakland sample actually worked with their hands. Indeed, Mueller (1969) found that $67 \%$ of proprietors and self-employed businessmen in her national sample operated machinery or equipment on their jobs. This percentage exceeds that of all the other groups classified as nonmanual, and is an additional reason to suspect that many self-employed blue-collar workers plying manual trades have been erroneously categorized as nonmanual.

The studies of mobility reviewed in this section were not based upon national samples, and therefore may lack generality. Nonetheless, selfemployment appears to be an avenue of mobility for blue-collar workers, though many fail in their attempts to achieve permanent advancement via this route. There is a tendency among students of social mobility to attribute high occupational prestige to the self-employed.

\section{Old and New Middle Class}

The literature on the old versus new middle class treats the entrepreneurial-bureaucratic dichotomy as an important aspect of the changes in values and behavior that have accompanied modernization. For many writers self-employment has been associated with the entrepreneurial orientation of the middle class and employment in organizations with the bureaucratic orientation of the new middle class. The literature on the negative effects of organizations upon individual members notwithstanding, some students of the old and new middle class tend to regard the growth of bureaucracy as a curse not upon those employed by organizations, but upon entrepreneurs who have survived from the prebureaucratic past and are in competition with big organizations. 
Barely able to hold their ground, they are increasingly alienated from the world of capital, technological innovation, rationalized production, and from society as a whole. They are seen as being made less well-off by the proliferation of organizations of which they are not members, and which render them marginal.

Some research has employed the strategy of comparing self-employed and wage-and-salary workers in order to study the differences between old and new middle class. Miller and Swanson (1958) showed that there were predictable differences in child-rearing practices between families classified as individuated-entrepreneurial and those classified as welfarebureaucratic. Although self-employment of the husband was a sufficient condition for classifying families as entrepreneurial, families were classified as entrepreneurial also if the husband gained at least half of his income in the form of profits, fees or commissions, if he worked in an organization having only two or fewer levels of supervision, or if either husband or wife was born on a farm or born outside the United States. Thus, the heads of some unknown proportion of the "entrepreneurial" families were employed by large organizations. Miller and Swanson emphasized that their conception as well as their operationalization of the entrepreneur includes much more than self-employment:

When we speak of entrepreneurs in this book we do not have in mind only persons who are self-employed or whose incomes depend heavily on the outcome of the risks they take. Our conception is much broader. We want to include under the label of entrepreneur all persons who, relatively more than the population at large, may be expected to have their lives strongly affected by individuated-entrepreneurial values . . . we call people "entrepreneurial" when they are more likely than others in our sample to have experiences that lead them to . . . entrepreneurial values (pp. 73-74; italics in original).

It is, thus, clear that Miller and Swanson studied not the effects of bureaucratic organizations on their members but rather intergenerational transmission of values through child-rearing practices in relation to type of social integration setting of families. This, together with their inclusion of some families with organizationally employed husbands in the entrepreneurial category, reduces the relevance of their work to the present discussion of the differences between the self-employed and members of work organizations.

Bonjean (1966) compared managers, hourly paid employees and independent businessmen in terms of their scores on "sociopersonality characteristics." Residents of the community studied were classified as businessmen according to three of Miller and Swanson's five criteria for distinguishing between entrepreneurs and bureaucrats (self-employment, 
working in an organization with two or fewer levels, and major income from profits, fees or commissions). Measures analyzed included an alienation index and three alienation subscales, plus anomie, self-actualization, self-esteem, self-estrangement, and status concern. The results showed that businessmen ranked between the managers and workers on all but two characteristics (they experienced the greatest amount of normlessness and had the lowest self-esteem) but, in general, more closely resembled the workers than the managers. The only characteristies on which the businessmen differed significantly from the workers was the powerlessness dimension of alienation; the workers reported significantly greater powerlessness. Workers and indepedent businessmen were more likely than managers to show social isolation, normlessness, anomie, low self-esteem, and general alienation. In addition, the businessmen displayed the least social participation and social involvement, both managers and workers ranking generally higher on these measures.

Bonjean's main objective was to test the hypothesis that industrialization and bureaucratization have had a leveling effect on social structure, and that the concept "middle mass" of mass society theory provides a more valid description of present day social structure than does traditional social class stratification theory. Secondarily he pointed out that "this sampling design permits an analysis of the relative effects of class and bureaucratic work setting on these same dependent variables" (p. 150). Had the managers and workers been consistently similar to each other but different from the businessmen, this would "suggest that bureaucratization is a leveling agent and that traditional indicators of social class no longer discriminate among those characteristics under investigation . . ." (p. 151). Consistent with his major objective, Bonjean considered similarities and differences among the three status occupation groups both in socioeconomic variables and in the sociopersonality characteristics and social participation as evidence for the mass or the class theory. However, in order to assess the effects of work setting on alienation and social participation, the effects of socioeconomic differences must be controlled prior to comparing those who work in organizations to those who are self-employed. The only differences between the three samples that Bonjean controlled were age, proportion with Spanish surname (which indirectly controlled religion), and education. Thus, socioeconomic status and bureaucratic-nonbureaucratic work setting were confounded. The scores for businessmen fall in between those of the managers and workers on all five of the socioeconomic variables reported, indicating that the sampling design yielded two groups of organization members that differed from each other substantially in socioeconomic 
status and a third group of self-employed nonmembers that embodied the full range of socioeconomic status among businessmen in the community studied. This same pattern-businessmen scoring somewhere between the two bureaucratically employed samples-again appeared in seven of the nine measures of sociopersonality variables, though it did not hold for the social participation measures. This repetitious patterning is suggestive of a relationship between socioeconomic status and sociopersonality characteristics that might hold irrespective of work setting, thus limiting the value of Bonjean's analysis for concluding anything about the effects of work setting (i.e., organizational membership) on sociopersonality characteristics.

In another analysis of the same data, Bonjean and Grimes (1970) investigated the association between five dimensions of bureaucracy and six measures of alienation among the three occupational status samples. They found no support for the generalization that there is a direct relationship between bureaucratization and alienation. Relationships between dimensions of bureaucratization and alienation were for the most part not significant for each of the three broad occupational groups, though the relationships were most pronounced among the hourly paid workers. Among businessmen all but one of the correlations between aspects of bureaucracy and dimensions of alienation were in the direction predicted by the generalization hypothesis and several were statistically significant. The relationships between bureaucracy and alienation were more often in the predicted direction and significant for the independent businessmen than they were for the salaried managers. These findings cast doubt upon the widely accepted generalization that something inherent in organizations alienates those who work in them. The relevant question appears to be which aspects of bureaucracy have which alienating effects upon which subclasses of workers? Evidently dimensions of bureaucracy have not only less predictable effects on higher-level members than on lower-level members, but also less association with alienation among upper-level organization members than among independent businessmen who do not even work in organizational settings. Obviously, the meaning of measures of bureaucratic concepts for workers not employed by organizations needs further clarification.

Nelson (1968) compared workers of the old and new middle class in terms of their anomie. He employed a two dimensional conceptualization of the old and new middle classes based on ownership and relationship to bureaucracy. He split his sample of Minnesota store managers first into owners and managers, depending on whether the head of the store owned the business or managed it for someone else. The sample of non- 
owning managers was further split into managers of small, independent stores and managers of moderate- and large-sized bureaucratic organizations. Similarly, business owners were split into two bureaucratic categories: independent businessmen of the "mom-and-pop store" variety (nonbureaucratic), and owners of businesses that operated under a corporate franchise (bureaucratic). He thus used a $2 \times 2$ design to test the relative effects of bureaucratic affiliation and owner-manager status on anomie among heads of stores. The initial findings indicated that, while owners showed significantly greater anomie than managers under both levels of bureaucratic affiliation, bureaucratic affiliation itself made no difference in anomie scores. Further analysis revealed that the difference between owners and managers were most pronounced at lower income levels, and were nonexistent for owners with incomes in excess of $\$ 10,000$. Even these differences were reduced to nonsignificance when the differences between owners and managers in their mobility commitments were controlled. The owners were more committed than the managers to their present economic positions, and less willing to move from their present community, relatives, and friends. Nelson's findings of an interaction between ownership and income in producing anomie, again, raises the question of how Bonjean's findings would have been altered had his sample of businessmen been split into high and low categories comparable in socioeconomic status to the managers and workers, respectively.

Trow's (1958) study of support for Senator Joseph McCarthy's methods of investigation among men in the new England town of Bennington can be regarded as a study of political alienation among different classes. He found that, controlling for differences in education, support for MeCarthy was greater among men who held both antiunion and anti-big business attitudes than among men with any other combination of attitudes towards those two "most characteristic economic institutions of our society." Trow noted that these men "are often angrily confused and deeply resentful of a world that continually offends their deepest values. . . This particular well of resentment and indignation has no effective and institutionalized channels of expression" (p. 276). In the Bennington sample small businessmen were disproportionately more likely than either manual or salaried men both to hold these doublenegative views and to support McCarthy. Trow explained:

Salaried employees . . . are in general not alienated from the dominant trends and institutions of modern society; these trends and developments of concentration, specialization, rationalization and bureaucratization have created the class of salaried employees and are its natural habitat. But, while accepting the general shape and direction of modern society, the 
salaried employees in Europe responded violently to short-run crises in capitalist society - to inflation, depression, mass unemployment, and their consequent insecurities of livelihood and social status....

By contrast, small businessmen react not so much to short-run crises in the economy as to its long range tendencies and direction of development against society itself rather than merely to failures of its economy. The tendencies which small businessmen fear . . proceed without interruption ...; thus they are always disaffected ... (p. 280; italics in original).

Trow's description is consistent with those social class theories that conceive of the self-employed entrepreneur as a vestige of an earlier era who is alienated from modern society because his position is threatened by dominant trends of industrialization and bureaucratization. The quotation also implies that salaried workers are comfortable in their bureaucratic settings.

Lipset (1960) reviewed studies of middle-class support for fascist political movements in Germany, Austria, France, Italy and the United States and found that fascism in all these countries has had exceptionally high appeal to the self-employed urban and rural middle classes, due in large part to the fact that these classes experience the insoluble frustrations of those who feel cut off from the main trends of modern society. Lipset described this tendency toward political fascism in a manner consistent with the old and new middle class literature:

Not only were these five national movements disproportionately backed by small independents, but in each country they secured much more support from those living on farms or in provincial small towns and cities. Here are the declining "liberal" classes living in declining areas. The petit bourgeosie of these sections not only suffer deprivation because of the relative decline of their class, they are also citizens of communities whose status and influence within the larger society is rapidly declining. From time to time, depending on various specific historical factors, their discontent leads them to accept diverse irrational protest ideologies - regionalism, racism, supernaturalism, anticosmopolitanism, McCarthyism, fascism (pp. 172-73).

Summarizing the research reviewed in this section, the self-employed are viewed as belonging to the old middle class, which is alienated from modern society and receptive to the appeal of right-wing political extremism, while new middle-class members of work organizations are by implication not alienated from society, due to their membership in the powerful organizations that increasingly render the old middle class economically marginal. There is evidence that members of the old middle class are not alienated unless they earn low incomes. This is not dissimilar from findings obtained from members of the new middle class. None of these studies has shown that membership in organizations has any effects upon alienation, the main dependent psychological variable 
studied. Finally, the responses given by independent businessmen to the measuring instrument used by Bonjean indicate that dimensions of bureaucracy can be measured as characteristics of nonorganizational work settings.

\section{Professionals in Organizational Settings}

Pelz and Andrews (1966) have pointed out that much scientific and professional work is now conducted in organizational settings. While their research included only scientists working within organizational settings, some of the studies on the effects of bureaucracy on professional workers have used the member-nonmember comparison. In his study of the role of bureaucratization as a barrier to professionalization, Wilensky (1964) compared salaried lawyers in the employ of law firms and solo lawyers. He found that bureaucracy "enfeebles the service ideal more than it threatens professional autonomy .. . where comfortable organizational routines take command, the salaried professional . . . may lose sight of client needs more quickly than his solo brother" (p. 148). "Anchored in neither organization nor colleague group, the sensitivity of the solo professional gravitates naturally to the customer" (p. 155).

Engel $(1968,1970)$ studied the effect of degree of bureaucratization on the professional autonomy of physicians. She compared physicians employed by two health care organizations characterized by different levels of bureaucratization and a third sample of solo practitioners who were self-employed in nonbureaucratic settings. She found that the highest level of professional autonomy was reported by physicians in the moderately bureaucratic setting; those in both nonbureaucratic and highly bureaucratic settings reported less autonomy. Engel explained this inverted $\mathrm{U}$-shaped relationship between bureaucratization and professional autonomy in terms of availability of resources. According to her interpretation, the self-employed practitioner does not possess the vast resources needed for the most advanced diagnostic and treatment procedures, and the highly bureaucratic organization may possess such resources but block access to them by member physicians. No data on resource accessibility were presented.

Scott (1966) has noted that all professionals in organizations may not be equally subject to bureaucratic control.

It appears that the higher the general prestige of the professional group and the more central their skills to the functioning of the organization, the more likely they are to be successful in their attempt to control the conditions under which they work. . . The division of spheres of authority typically found in hospitals, clinics, and universities in which professionals assume relatively complete control over professional matters and submit 
to representatives of management only in administrative matters is one indication of the extent to which highly prestigious and high centrality professional groups can gain control over the conditions under which they work (p. 275).

Professional workers bring their entrepreneurship with them into the organization as part of their professional work, and, as Vollmer (1966) has observed, "entrepreneurial activities and interests are facts to be reckoned with in a variety of modern organizational settings" (p. 278). To the extent that a relationship between occupational level and subjugation to bureaucratic control is generalizable to nonprofessional groups, the following interaction hypothesis is plausible: The effects of organizational membership depend on the occupational level of the workers. For those at lower occupational levels self-employment can serve as a means of escaping bureaucratic control, while those working at higher occupational levels are relatively free of such control even when employed by bureaucratic organizations.

There is nothing in these studies that shows ill effects of organizational membership on professionals. It should be noted that in Engel's study neither group of member physicians reported less professional autonomy than did self-employed practitioners.

\section{Job Satisfaction and Mental Health}

The measures of job satisfaction that have been used so extensively with various organizational populations have not been applied to the self-employed for comparative purposes. None of the major reviews of the vast literature on job satisfaction has included a study of job satisfaction among self-employed workers (Brayfield \& Crockett, 1955; Herzberg, Mausner \& Snyderman, 1959; Smith, Kendall \& Hulin, 1969; Vroom, 1964). This is astonishing in light of the nonempirical literature on the effects of organizations on their members, discussed in an earlier section.

The aforementioned national survey data collected by Kahn et al. (1964, Appendix B) are presented now. These data, obtained by means of questionnaire measures, reveal some differences between self- and other-employed workers, and suggest that men and women respond differently to self-employment. The largest and most consistent difference between self- and other-employed workers is in the percentage reporting some job-related worries in open-ended questions. While $80 \%$ of the self-employed workers reported job-related worries, only $52 \%$ of the wage-and-salary workers reported such problems. This difference is found among both men and women, and among males for every age category and for every educational level. (There were not enough 
self-employed women in the national sample to permit tertiary controls.) The next most consistent difference is that while $55 \%$ of the wage-andsalary men reported having been absent from their jobs for at least 1 day during the year prior to the survey, only $31 \%$ of the self-employed men reported such absence. This difference holds across four out of five age intervals and among all five educational levels. Among women there is no parallel difference in absence. Although in industrial mental health research absence is usually taken as an indicator of strain, the low absence rate for self-employed men can be explained as a manifestation of their indispensability to their businesses rather than as an indication of less strain. Regarding health, roughly a quarter of the men and women in each job setting reported themselves in less than excellent health. Taken together these findings suggest that while the self-employed of both sexes experience relatively more job-related worries than do wageand-salary employees, the self-employed men have less of a chance to escape from those worries via absence from the job.

"Job-related tension" was measured with a 15 -item index, and mean scores were reported for self- and other-employed workers. The mean scores for men differ by only a tenth of a point. Among women the self-employed scored 2.0 while the wage-and-salary employees averaged only 1.5 , providing evidence for greater tension among the former. Since the variances were not provided in the appendix, it is impossible to test these differences for significance. Another indication that self-employment may have more ill effects on women than on men is shown by the percentage reporting that their job satisfaction has decreased since beginning their present job. Only $9 \%$ of the wage-and-salary women reported such a drop in job satisfaction as compared to $39 \%$ for selfemployed women; among men there was no appreciable difference. The data for self-employed women must be interpreted with caution since their number in these tables never exceeds 33 .

In sum, perhaps the outstanding feature of these data is the general similarity between self- and other-employed men. Only in job-related worries and absence from work do the self-employed differ. They are strikingly similar in health, job satisfaction, job-related tension, and sense of being "caught in the middle," a measure of role conflict. While women, like men, are more likely to report job-related worries if they are self-employed, women also experience more tension and less job satisfaction as a consequence of their self-employment.

An earlier national survey of mental health taken by Gurin, Veroff, and Feld (1960) obtained data consistent with the conclusion that the selfemployed worry more about their jobs. They reported that managers, salesmen and farmers more frequently than workers in other occupational 
categories spontaneously mentioned the job as a source of worries in response to a question about general adjustment. Gurin et al. discerned that "these three occupations have in common an entrepreneurial focus and a dimension of self-direction which doubtless make these occupations a more salient concern for the men who work at them" (p. 228). Gurin et al. did not analyze the self-employed separately.

\section{SUMMARY AND CONCLUSIONS}

Self-employment as such has not been investigated systematically and studies that have included self-employed workers have not built upon one another. The job satisfaction literature appears to have utterly ignored the self-employed. Thus, the search for information about the self-employed leads one to literature on bureaucratization, professionalization, social class, political behavior, and economic behavior. The discontinuity to this research is evident from the general lack of crossreferencing and the unfortunate fact that few of these studies have used the same dependent variables. Research on dependent variables at the individual level has lacked controls needed to eliminate the effects of demographic differences on these outcome measures and, thus, has confounded demographic variables with bureaucratic-nonbureaucratic work setting. For example, it is not known whether self-employed workers are more susceptible to fascist political appeal than are wage-and-salary workers of the same income, age, education, sex, race, etc. Studies that have used such controls have usually either reduced or eliminated the differences between self-employed and wage-and-salary workers. It is apparent that multivariate statistical controls will have to be employed in any study using the comparative approach urged in this paper.

The picture of self-employed workers that emerges from the literature reviewed is one of a surviving class of entrepreneurs whose period of political and economic reign has passed and who are alienated from the new middle class dominant in industrialized society. At the same time, they are less alienated than hourly wage earners in bureaucratic organizations. They are disproportionately susceptible to fascist political ideology. As a group they work many more hours for somewhat higher annual income, though their income may be lower than that of their organizationally employed counterparts, depending on their occupation. If he is a professional, the self-employed worker may be more open to influence from his clients than is his bureaucratically controlled counterpart in the employ of an organization, and his professional autonomy may be roughly equivalent to, or somewhat more rational than, that of the organizationally employed professional, depending upon the degree of bureaucratization of the latter's setting. An important subgroup of 
self-employed workers are those who are attempting to achieve intragenerational mobility when they lack the credentials required for advancement via organizational employment. Farmers are another distinctive subgroup among the self-employed. Clearly, the self-employed are a highly diverse category of workers that probably shows as much variation on most characteristics as the rest of the work force. Their diversity and uniqueness have undoubtedly contributed to their being treated as a nuisance in most research on the psychology of work. One suspects that a reason for frequently classifying all the self-employed together in occupational status codes is that it facilitates their elimination from analysis.

It is interesting that while the alienation of the industrial employee is attributed to the stifling effects of bureaucratic organization upon him, the alienation of the small independent entrepreneur is attributed to his being denied what organizations can offer. There are many persuasive treatises on the victimization of subpopulations by organizations. There has been a tendency to attribute undesirable features of modern life to organizations in the form of plausible, though untested, assertions, when these effects might in actuality have their sources elsewhere. Bureaucratization may be a factor contributing to everybody's alienation through pervasive societal processes that operate irrespective of work setting. While it may do violence to the traditional meaning of the word, "bureaucracy," defined as the extensive presence of certain characteristies in work settings, may be as prevalent in the situation of the self-employed person working "alone" as it is in organizational work settings. Perhaps a great deal of what has been attributed to "bureaucracy" occurs in all work settings and has, thus, been mislabeled and misconceived. To call certain empirical events "bureaucratic" when they occur in organizations, and to withhold that label when the same events take place in nonorganizational settings, could lead to a diversion of attention from the real issues. Utilization of the self-employed as a comparison group could reveal what organizations are--and are not-doing to the individuals employed by them.

\section{REFERENCES}

Argyris, C. Personality and organization. New York: Harper, 1957.

ARgrRIs, C. Individual actualization in complex organizations. Mental Hygiene, 1960, 44, 226-237.

ARGYRIS, C. Integrating the individual and the organization. New York: Wiley, 1964.

Blauner, R. Alienation and freedom: The factory worker and his industry. Chicago: University of Chicago Press, 1964.

BonjeAr, C. M. Mass, class, and the industrial community: A comparative analysis 
of managers, businessmen, and workers. American Journal of Sociology, 1966, 72, 149-162.

Bonjean, C. M., \& Grimes, M. D. Bureaucracy and alienation: A dimensional approach. Social Forces, 1970, 48, 365-373.

Brayfield, A. H., \& Crockett, W. H. Employee attitudes and employee performance. Psychological Bulletin, 1955, 52, 396-424.

Chinoy, E. Automobile workers and the American dream. Garden City, NY: Doubleday, 1955.

Datton, M. Men who manage: Fusions of feeling and theory in administration. New York: Wiley, 1959.

ENgen, G. V. The effect of bureaucracy on the professional autonomy of the physician. (Doctoral dissertation, University of California, Los Angeles) Ann Arbor, MI: University Microfilms, 1968, No. 68-16,603.

ENGel, G. V. Professional autonomy and bureaucratic organization. Administrative Science Quarterly, 1970, 15, 12-21.

Fine, B. D. Comparison of organizational membership and self-employment. (Doctoral dissertation, The University of Michigan) Ann Arbor, MI: University Microfilms, 1970, No. 71-23,751.

FINE, S. A. Older workers in pursuit of new careers. In H. L. Sheppard (Ed.), Toward an industrial gerontology: An introduction to a new field of applied research and services. Cambridge, MA: Schenkman, 1970.

Gurin, G., Veroff, J., \& Fetd, S. Americans view their mental health. New York: Basic Books, 1960.

HaLL, R. H. Bureaucracy and small organizations. Sociology and Social Research, $1963,48,38-46$.

Herzberg, F., Mausner, B., \& Snyderman, B. The motivation to work. (2nd ed.) New York: Wiley, 1959.

Kahn, R. L., Wolfe, D. M., Quinn, R. P., Snoek, J. D., \& Rosenthal, R. A. Organizational stress: Studies in role conflict and ambiguity. New York: Wiley, 1964.

Katz, F. E. Autonomy and organization: The limits of social control. New York: Random House, 1968.

Leveson, I. Some determinants of nonfarm self-employment. Monthly Labor Review, May, 1968, 11-15. (a)

Leveson, I. F. Nonfarm self-employment in the U. S. (Doctoral dissertation, Columbia University) Ann Arbor, MI: University Microfilms, 1968. No. 68-11,721 (b)

Lipset, S. M. Political man. Garden City, NY: Doubleday, 1960.

LIPSET, S. M., \& Bendix, R. Social mobility in industrial society. Berkeley, CA: University of California Press, 1959.

MaYer, K. Small business as a social institution. Social Forces, 1947, 14, 332-349.

Merton, R. K. Social theory and social structure. (Rev.ed.) New York: Free Press, 1957.

Miller, D. R., \& Swanson, G. E. The changing American parent: A study in the Detroit area. New York: Wiley, 1958.

MrLss, C. W. White collar: The American middle classes. New York: Oxford University Press, 1951.

Morgan, J. N., Srrageldin, I., \& Baerwaldt, N. Productive Americans: A study of how individuals contribute to economic progress. Ann Arbor, MI: Institute for Social Research, 1966. 
MunLLER, E. Technological advance in an expanding economy: Its impact on a cross-section of the labor force. Ann Arbor, MI: Institute for Social Research, 1969.

Murretl, K. F. H. Major problems of industrial gerontology. In H. L. Sheppard (Ed.), Toward an industrial gerontology: An introduction to a new field of applied research and services. Cambridge, MA: Schenkman, 1970.

Nelson, J. I. Anomie: Comparisons between the old and new middle classes. American Journal of Sociology, 1968, 74, 184-192.

Pelz, D. C., \& Andrews, F. M. Scientists in organizations: Productive climates for research and development. New York: Wiley, 1966.

Perlulps, J. D. The self-employed in the United States. Urbana, II: University of Illinois, 1962.

Porter, L. W., \& Lawler, E. L. Properties of organization structure in relation to job attitudes and job behavior. Psychological Bulletin, 1965, 64, 23-51.

Prestrus, $\mathrm{R}$. The organization society: An analysis and a theory. New York: Vintage, 1962.

Reiss, A. J., Jr. Occupational mobility of professional workers. American Sociological Review, 1955, 20, 693-700.

Scott, W. R. Professionals in bureaucracies-Areas of conflict. In H. M. Vollmer, \& D. L. Mills, (Eds.), Professionalization. Englewood Cliffs, NJ: Prentice-Hall, 1966. Pp. 265-275.

Sмiтн, P. C., Kandall, L. M., \& Hulin, C. L. The measurement of satisfaction in work and retirement: A strategy for the study of attitudes. Chicago: RandMeNally, 1969.

Trow, M. Small businessmen, political tolerance, and support for McCarthy. American Journal of Sociology, 1958, 64, 270-281.

VolLmer, H. M. Entrepreneurship and professional productivity among research scientists. In H. M. Vollmer \& D. L. Mills (Eds.), Professionalization. Englewood Cliffs, NJ: Prentice-Hall, 1966.

Vroom, V. H. Work and motivation. New York: Wiley, 1964.

WeBer, M. The theory of social and economic organization. (Translated by A. M. Henderson and T. Parsons.) New York: Free Press, 1947.

Wнтте, W. H. The organization man. New York: Simon \& Schuster, 1956.

WICKer, A. W. Attitudes versus action: The relationship of verbal and overt behavioral responses to attitude objects. Journal of Social Issues, 1969, 25, 41-78.

Wilensky, H. L. The professionalization of everyone? American Journal of Sociology, 1964, 70, 137-158.

RECEIVED: February 24, 1972 